\title{
Vitamin D Levels and Hepatitis B: Is There Any Relationship?
}

\author{
Vitamin D Düzeyleri ve Kronik Hepatit B: Bir llișki Var mı?
}

\author{
Aslıhan CANDEVIR ULU, Ferit KUŞÇU, Ayşe Seza INAL, Süheyla KÖMÜR, Behice KURTARAN, \\ Selçuk NAZIK, Yeşim TAŞOVA, Hasan Salih Zeki AKSU
}

Çukurova University Faculty of Medicine, Department of Infectious Diseases and Clinical Microbiology, Adana, Turkey

\begin{abstract}
Objective: It has been shown that vitamin D has very important biologic effects including cell differentiation, inhibition of proliferation and immune modulation. Vitamin D levels may affect the immune system and host response to viral infections, such as hepatitis B virus (HBV) infection. Our aim in this study was to see whether or not there is a relationship between vitamin D levels and chronic HBV infection.

Materials and Methods: Patients who were admitted to the infectious diseases outpatient clinic with chronic HBV infection between January and March 2013 were enrolled as cases. Controls were chosen randomly among individuals admitted to the outpatient clinic at the same time period and otherwise healthy.

Results: Ninety chronic HBV cases and 76 controls were included in the period of study. Thirty-three (42.2\%) of the control and 39 (43.3\%) of the case groups were male. The mean age and vitamin $D$ levels of the case and control groups were; $39.9 \pm 13.3$ years, $43.0 \pm 13.3$ years and $11.7 \pm 6.6 \mathrm{ng} / \mathrm{ml}, 16.2 \pm 8.7 \mathrm{ng} / \mathrm{ml}$, respectively. Vitamin $D$ levels were significantly lower in the case group $(p<0.001)$. There was no significant difference in vitamin $\mathrm{D}$ levels between the treatmentfree group and treatment group $(14.0 \pm 6.9 \mathrm{ng} / \mathrm{ml}, 11.0 \pm 6.3 \mathrm{ng} / \mathrm{ml}$, respectively; $p>0.05)$. There was no correlation between HBV DNA and vitamin D levels.

Conclusion: Vitamin D levels were found to be lower in chronic HBV patients in our study which was designed as case-control. Prospective, well-designed and controlled studies are needed to show its effect on the course of chronic hepatitis B.

Key Words: Hepatitis B, vitamin D, immunity
\end{abstract}

ÖZET

Amaç: Yapılan çalışmalar sonucunda vitamin D'nin hücre farklılaşması, proliferasyonun inhibisyonu ve immun modulasyon gibi çok önemli biyolojik etkilerinin olduğu gösterilmiştir. Vitamin D düzeylerinin, hepatit B virüs (HBV) enfeksiyonu gibi viral enfeksiyonlara karşı immün sistem ve konak yanıtını etkileyebileceği düşünülmektedir. Bu çalışmanın amacı vitamin D düzeyleri ve kronik HBV enfeksiyonu arasında ilişki olup olmadığını araştırmaktır.

Gereç ve Yöntemler: Hastanemiz Enfeksiyon Hastalıkları polikliniğine kronik HBV enfeksiyonu tanısıyla Ocak ve Mart 2013 tarihleri arasında başvuran hastalar çalışmaya dahil edilmiştir. Kontrol grubu olarak aynı zaman aralığında polikliniğe başvuran ve kronik herhangi bir hastalığı olmayan hastalar alınmıştır.

Bulgular: Doksan hasta ve 76 kontrol hastası, çalışmaya dahil edildi. Kontrol grubunun 33'ü $(\% 42,2)$ ve olgu grubunun 39'u (\%43,3) erkekti. Olgu ve kontrol grubunun ortalama yaș ve vitamin $\mathrm{D}$ düzeyleri sırasılyla; $39,9 \pm 13,3$ yıl ile $43,0 \pm 13,3$ yıl ve $11,7 \pm 6,6 \mathrm{ng} / \mathrm{ml}$ ile 16,2 $\pm 8,7$ $\mathrm{ng} / \mathrm{ml}$ idi. Vitamin $D$ düzeyleri olgu grubunda anlamlı derecede düşüktü $(p<0,001)$. Antiviral tedavi alan ve almayan hastalar arasında vitamin $D$ düzeyleri açısından istatistiksel olarak anlamlı farklılık yoktu $(14,0 \pm 6,9 \mathrm{ng} / \mathrm{ml}$ ve $11,0 \pm 6,3 \mathrm{ng} / \mathrm{ml}, \mathrm{p}>0,05)$. HBV DNA ve vitamin D düzeyleri arasında bir korelasyon tespit edilmedi.

Sonuç: Olgu-kontrol düzeni ile tasarlamış olduğumuz bu çalışmada vitamin D düzeyleri kronik HBV'li hastalarda daha düşük bulunmuştur. Vitamin D'nin kronik HBV seyri üzerindeki etkisini net olarak gösterebilmek için daha detaylı tasarlanmış, prospektif ve kontrollü çalışmalara intiyaç vardır.

Anahtar Kelimeler: Hepatit B, vitamin D, bağışıklık

\section{Introduction}

Having an effective vaccine, hepatitis B virus (HBV) infection is still an important healthcare issue and one of the most frequent important chronic infectious diseases. It is estimated that more than 2 billion people were infected with HBV and more than 400.000 people have chronic disease $(1,2)$. The course of the disease is determined by the viral replication and the immune response of the host. The disease is usually asymptomatic but it is still one of the major reasons of cirrhosis and hepatocellular carcinoma (3).

Vitamin $D$ is an essential part of human diet having a traditional role in bone mineralization. It has been shown that vitamin $D$ 
has very important biologic effects including cell differentiation, inhibition of proliferation and immune modulation (4). There are several studies on the relationship between vitamin $D$ levels and viral infections $(5,6)$. It has been shown that vitamin $D$ presents its antimicrobial activity by expression of cathelicidin (LL-37) $(7,8)$. 1.25 dihydroxy-vitamin $\mathrm{D}\left(1.25(\mathrm{OH})_{2}\right.$ vitamin $\left.\mathrm{D}\right)$ induces cathelicidin releasing from the neutrophil granules via the vitamin $D$ receptors (VDR). Cathelicidin primarily target enveloped virus by disrupting the lipid membrane of the envelope and also block the viral entry into the host cell (9). The relationship between treatment response and low vitamin $D$ levels are shown in hepatitis $C$ virus $(\mathrm{HCV})$ infections but there are not many studies investigating the relationship of hepatitis $B(10,11)$.

Our aim in this study was to see whether or not there is a relationship between vitamin D levels and chronic HBV infection.

\section{Materials and Methods}

\section{Patients}

Ninety patients who were admitted to the infectious diseases outpatient clinic with the diagnosis of chronic hepatitis B $(\mathrm{HbsAg}$ positive, anti-Hbs negative for at least six months) between January and March 2013 were enrolled as cases. Similar group of 79 patients without a history or serological proof of chronic HBV infection and chronic diseases admitted to the outpatient clinic were chosen as controls retrospectively. People with calcium or vitamin D replacement therapy, chronic renal disease, heart failure, bone diseases, thyroid diseases and infectious diseases, such as hepatitis $\mathrm{C}$ and HIV were excluded. Demographics of the patients and controls were recorded. Treatments and responses were also investigated for the chronic HBV infection patients.

Blood samples were taken into EDTA tubes from the patients for detection of serum 25-hydroxy vitamin D $(25(\mathrm{OH}) \mathrm{D})$ levels. Serum 25(OH)D levels were measured with chromatographic method using a Shimadzu LC 20AD/T series (Kyoto, Japan) HPLC device in our hospital central laboratory. Normal values of $25(\mathrm{OH}) \mathrm{D}$ levels were $10-69 \mathrm{ng} / \mathrm{ml}$ in the study period. 25(OH)D values under $10 \mathrm{ng} / \mathrm{ml}$ were considered as vitamin D insufficiency.

Normality distribution of variables was tested with the Kolmogorov-Smirnov test. Student-t test was used for normally distributed variables and the Mann-Whitney $U$ test was used for the analysis of variables not showing normal distribution. Chi-Square and Fischer's exact test were used for analysis of categorical variables. Spearman's correlation coefficient was used for correlation analysis. Data were shown as mean \pm standard deviation (SD), median, number (n) and percent (\%). STATA 12.0 program was used for data analysis and a p level of less than 0.05 was considered statistically significant.

\section{Results}

Ninety cases and 76 controls were included in the period of study. Thirty-three $(43.4 \%)$ of the controls and 39 (43.3\%) of the case group were male. Genders were similar in case and control groups $(p=0.991)$. The mean age of the case and control groups were, $39.9 \pm 13.3$ years and $43.0 \pm 13.3$ years, respectively and there was no statistically significant difference between the groups $(p=0.135)$ (Table 1).

Vitamin D levels in the case and control groups were; $11.7 \pm 6.6$ $\mathrm{ng} / \mathrm{ml}, 16.2 \pm 8.7 \mathrm{ng} / \mathrm{ml}$, respectively. Vitamin $D$ levels were significantly lower in the case group $(p<0.001)$ than in controls (Figure 1). When categorized as normal and insufficient, $25(\mathrm{OH}) \mathrm{D}$ levels were significantly lower in the case group ( $p<0.001$, Odds Ratio (OR): 4.05, 95\% GA: 1.98-8.26) (Table 1). There was no difference in vitamin $D$ levels between genders; $13.6 \pm 5.7 \mathrm{ng} / \mathrm{ml}$ in males and $13.9 \pm 9.3 \mathrm{ng} / \mathrm{ml}$ in females $(p=0.846)$.

In the case group, 21 of 90 patients were on antiviral treatment. Twelve patients were on tenofovir (57.1\%), four were on entecavir $0.5 \mathrm{mg}(19 \%)$, two were on entecavir $1 \mathrm{mg}(9.5 \%)$, two were on telbivudine (9.5\%) and one was on lamivudine (4.8\%).

\begin{tabular}{|c|c|c|c|}
\hline & $\begin{array}{l}\text { Case }(n=90) \\
\text { Mean } \pm \text { SD/n, }(\%)\end{array}$ & $\begin{array}{l}\text { Control }(n=76) \\
\text { Mean } \pm S D / n,(\%)\end{array}$ & $p$ value \\
\hline Age & $39.9 \pm 13.3$ & $43.0 \pm 13.3$ & 0.135 \\
\hline \multicolumn{4}{|l|}{ Gender } \\
\hline Male & 39 (43.3\%) & $33(43.4 \%)$ & \multirow{2}{*}{$\begin{array}{l}0.991 \\
\text { OR: } 0.99 \\
95 \% \mathrm{Cl}: \\
0.53-1.84\end{array}$} \\
\hline Female & 51 (56.7\%) & $43(56.6 \%)$ & \\
\hline $\begin{array}{l}25(\mathrm{OH}) \mathrm{D} \\
(\mathrm{ng} / \mathrm{ml})\end{array}$ & $11.7 \pm 6.6$ & $16.2 \pm 8.7$ & $<0.001$ \\
\hline \multicolumn{4}{|l|}{$25(\mathrm{OH}) \mathrm{D}$} \\
\hline Low & $43(47.8 \%)$ & $14(24.6 \%)$ & \multirow{2}{*}{$\begin{array}{l}<0.001 \\
\text { OR: } 4.05 \\
95 \% \text { GA: } \\
1.98-8.26\end{array}$} \\
\hline Normal & 47 (52.2\%) & $62(81.6 \%)$ & \\
\hline
\end{tabular}

\begin{tabular}{|l|l|l|l|}
\hline \multicolumn{2}{|l|}{ Table 2. Comparison of age, gender and 25(OH)D levels between patients on treatment and not on treatment } \\
\hline & $\begin{array}{l}\text { On treatment (n=21) } \\
\text { Mean } \pm \text { SD/n, (\%) }\end{array}$ & $\begin{array}{l}\text { Not on treatment (n=69) } \\
\text { Mean } \pm \text { SD/n, (\%) }\end{array}$ & p value \\
\hline Age & $38.7 \pm 15.0$ & $40.2 \pm 12.9$ & 0.645 \\
\hline Gender & $14(66.7 \%)$ & $25(36.2 \%)$ & 0.016 \\
\hline Male & $7(33.3 \%)$ & $44(63.8 \%)$ & $\begin{array}{l}\text { OR: 3.52 } \\
95 \% \text { Cl: } 1.25-9.87\end{array}$ \\
\hline Female & $14.0 \pm 6.9$ & $11.0 \pm 6.3$ & 0.069 \\
\hline $25(\mathrm{OH}) \mathrm{D}(\mathrm{ng} / \mathrm{ml})$ & $9(42.9 \%)$ & $3(4.3 \%)$ & 0.0002 \\
\hline Hbe Ag positive & & & \\
\hline
\end{tabular}




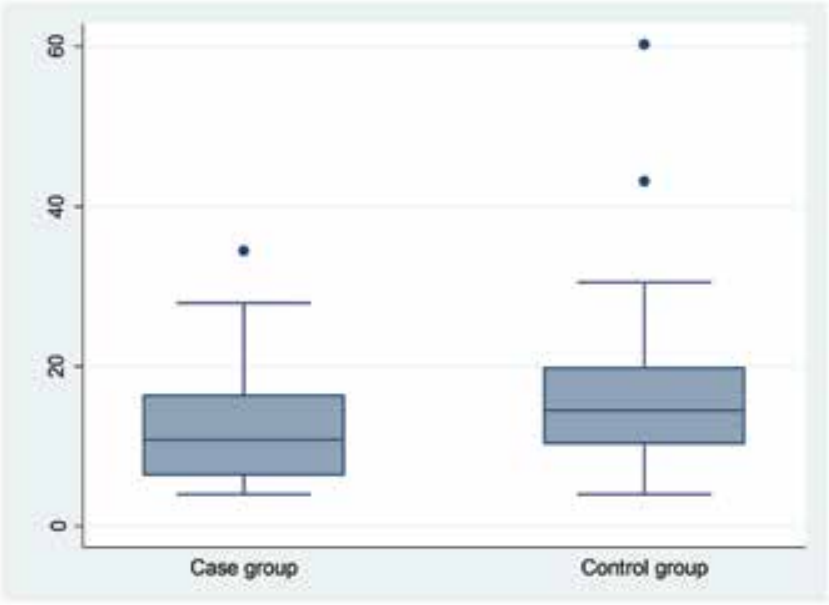

Figure 1. Mean vitamin D levels of case and control groups

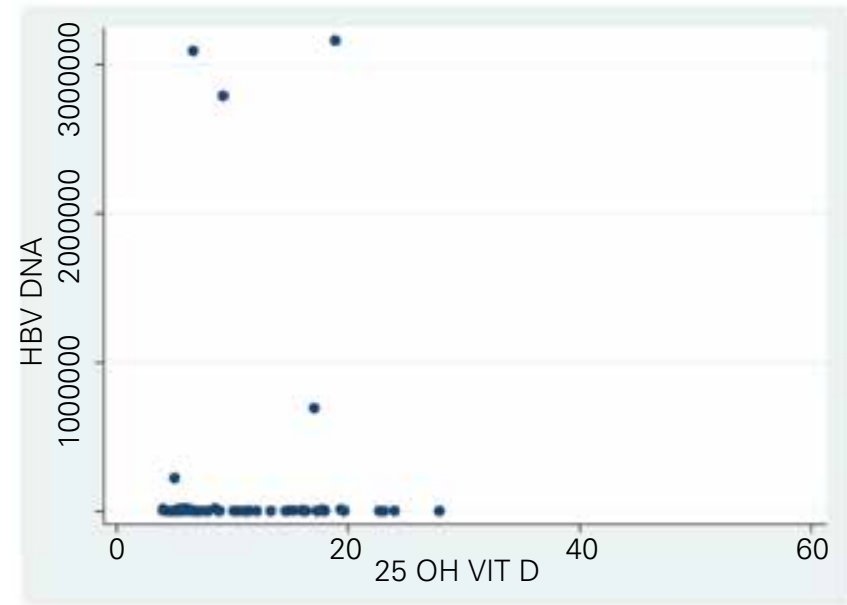

Figure 2. Distribution graphic of HBV DNA and vitamin D levels

There was no difference between age of patients having treatment and not having treatment $(p=0.069)$. There were more male patients in the treatment group $(p=0.016)$. Vitamin $D$ levels were higher in the treatment group, however, the difference was not statistically significant $(14.0 \pm 6.9 \mathrm{ng} / \mathrm{ml}$ vs. $11.0 \pm 6.3 \mathrm{ng} /$ ml) $(p=0.069)$. Vitamin $D$ levels and demographic features of these groups are showed in Table 2. There was no correlation between vitamin D levels and HBV DNA levels (Figure 2).

Of the chronic HBV patients, 12 were HBeAg positive and 76 were negative, two patients' condition was unknown. Vitamin $D$ levels in $\mathrm{HBeAg-positive} \mathrm{and} \mathrm{negative} \mathrm{patients} \mathrm{were}$ $14.94 \pm 5.62 \mathrm{ng}$ and $10.89 \pm 5.62 \mathrm{ng}$, respectively and there was no statistically significant difference $(p=0.153)$.

Liver biopsy was performed in only 12 patients. There was no relationship between vitamin $D$ levels and histological activity index $(p=0.997)$. There was no relationship between fibrosis and vitamin D levels $(p=0.425)$.

\section{Discussion}

The antimicrobial effect of vitamin $D$ is thought to be via secretion of cathelicidin (in LL-37 form), human betadefencin-2 and reactive radicals of oxygen (9). LL-37 shows bactericidal effect by shivering the bacterial membrane by electrostatic interaction. Similar effect can occur on lipid envelopes of the viruses (12). Most of the studies revealing the positive effect of vitamin $D$ on immunity were about infections caused by enveloped viruses (9). Theoretically, molecules occurred through vitamin D should have antimicrobial effect on $\mathrm{HCV}$ and HBV because of their being enveloped.

There are studies in the literature about the relationship between vitamin $D$ and chronic hepatitis, particularly hepatitis C. In the study by Bitetto et al. (10) the treatment response with standard interferon and ribavirin was worse in hepatitis $\mathrm{C}$ patients with vitamin D levels lower than $10 \mathrm{ng} / \mathrm{ml}$. Petta et al. (11) found a relationship between liver fibrosis and vitamin $D$ levels in addition. In our study, we believe that because of the low rates of liver biopsy, we could not find any relationship between vitamin $\mathrm{D}$ levels and histological activity index and fibrosis.

Vitamin D affects the calcium metabolism and immunity through the VDR (13). A case-control study from Gambia performed on 2015 people identified that polymorphism caused by a base change in the $352^{\text {th }}$ codon of VDR receptor gene plays a role in hepatitis $B$ being chronic. The identification of the role of receptor polymorphism in chronic hepatitis $B$ makes us think that low serum levels of $25(\mathrm{OH}) \mathrm{D}$ may have an effect on the course of chronic hepatitis B (14). Thus, in the study by Demir et al. (15), 25(OH)D levels were significantly lower in the case group than in the immune and healthy control groups. Similarly, we found that chronic HBV patients had lower levels of $25(\mathrm{OH})$ $\mathrm{D}$ than the control group. Besides, our levels were also lower than in a study by Uçar et al. (16) investigating vitamin D levels in the general population (mean 25(OH)D levels in females and males were $24.02 \pm 16.93$ and $22.76 \pm 8.52$, respectively).

Farnik et al. (17) stated that low levels of $25(\mathrm{OH}) \mathrm{D}$ was the predictor of high viral replication and showed that $25(\mathrm{OH}) \mathrm{D}$ levels were significantly lower in patients with HBV DNA levels $>2000 \mathrm{lU} / \mathrm{ml}$. Besides, 25(OH)D levels were significantly lower in patients who were $\mathrm{HBe}$ antigen positive. In our study, we did not find a correlation between HBV DNA levels and 25(OH)D levels. There was also no relationship between vitamin $D$ levels and $\mathrm{HBe}$ antigen status. Low patient number and seasonal change of vitamin $D$ levels were thought to be the reasons for the lack of correlation.

Some limitation should be considered when evaluating our study. First of all, not having naturally immune people as controls prevents us to show the effect of vitamin $D$ on chronicity of hepatitis B. Since vitamin D works through VDR, not looking at the gene polymorphism for VDR could have lead to some patients' being overlooked even if they had immune deficiency for hepatitis $B$.

As a result, even though we determined that $25(\mathrm{OH}) \mathrm{D}$ levels were lower in chronic hepatitis B patients, prospective multicenter randomized controlled studies designed in order to show if these low levels cause difference in the course of the disease, development of complications like cirrhosis or hepatocellular cancer or to treatment response, will help gathering scientific knowledge with higher evidence level. 
Ethics Committee Approval: No ethics approval needed because of retrospective design, Informed Consent: No informed consent needed, Concept: Aslıhan Ulu, Design: Aslıhan Ulu, Ferit Kuşçu, Data Collection or Processing: Aslıhan Ulu, Ferit Kuşcu, Selçuk Nazik, Analysis or Interpretation: Aslıhan Ulu, Ferit Kuşçu, Literature Search: Aslıhan Ulu, Ferit Kuşcu, Ayşe Seza Inal, Süheyla Kömür, Behice Kurtaran, Selçuk Nazik, Yeşim Taşova, Hasan Salih Zeki Aksu, Writing: Aslıhan Ulu, Ferit Kuşçu, Ayşe Seza Inal, Süheyla Kömür, Behice Kurtaran, Selçuk Nazik, Yeşim Taşova, Hasan Salih Zeki Aksu, Peer-review: External and Internal peer-reviewed, Conflict of Interest: No conflict of interest was declared by the authors, Financial Disclosure: The authors declared that this study has received no financial support.

\section{References}

1. McMahon BJ. Chronic hepatitis B virus infection. Med Clin North Am. 2014; 98: 39-54.

2. Lai $C L$, Ratziu $V$, Yuen MF, Poynard T. Viral hepatitis B. Lancet. 2003; 362(9401):2089-2094.

3. Ganem D, Prince AM. Hepatitis B virus infection-natural history and clinical consequences. N Engl J Med. 2004; 350: 11181129.

4. Kitson MT, Roberts SK. D-livering the message: the importance of vitamin D status in chronic liver disease. J Hepatol. 2012; 57: 897-909.

5. Loke H, Bethell D, Phuong CX, Day N, White N, Farrar J, Hill A. Susceptibility to dengue hemorrhagic fever in vietnam: evidence of an association with variation in the vitamin $d$ receptor and Fc gamma receptor Ila genes. Am J Trop Med Hyg. 2002; 67: 102-106.

6. Holmoy T. Vitamin D status modulates the immune response to Epstein Barr virus: Synergistic effect of risk factors in multiple sclerosis. Med Hypotheses. 2008; 70: 66-69.

7. Sorenson OE, Follin P, Johnsen A, Calafat J, Tjabringa GS, Himestra PS, Borrenqaard N. Human cathelicidin, hCAP-18, is processed to the antimicrobial peptide LL-37 by extracellular cleaveage with proteinase 3. Blood. 2001; 97: 3951-3959.

8. Bergmana P, Walter-Jallow L, Broliden K, Agerberth B, Söderlund J. The antimicrobial peptide LL-37 inhibits HIV-1 replication. Curr HIV Res. 2007; 5: 410-415.

9. Beard JA, Bearden A, Striker R.Vitamin D and the anti-viral state. J ClinVirol. 2011; 50: 194-200.

10. Bitetto D, Fabris C, Fornasiere E, Pipan C, Fumolo E, Cussigh A, Bignulin S, Cmet S, Fontanini E, Falleti E, Martinella R, Pirisi $M$, Toniutto P. Vitamin D supplementation improves response to antiviral treatment for recurrent hepatitis C. Transpl Int. 2011; 24: 43-50.

11. Petta $S$, Cammà $C$, Scazzone $C$, Tripodo $C$, Di Marco V, Bono A, Cabibi D, Licata G, Porcasi R, Marchesini G, Craxí A. Low vitamin $D$ serum level is related to severe Şbrosis and low responsiveness to interferon-based therapy in genotype 1 chronic hepatitis C. Hepatology. 2010; 51: 1158-1167.

12. Bals R, Wilson JM. Cathelicidins- a family of multifunctional antimicrobial peptides. Cell Mol Life Sci. 2003; 60: 711-720.

13. Eisman JA. Vitamin $D$ receptor gene variants: implication for therapy. Curr Opin Genet Dev. 1996; 6: 361-365.

14. Bellamy R, Ruwende C, Corrah T, McAdam KP, Thursz M, Whittle HC, Hill AV. Tuberculosis and chronic hepatitis B virus infection in Africans and variation in the vitamin $D$ receptor gene. J Infect Dis. 1999; 179: 721-724.

15. Demir C, Demir M. Vitamin D levels in patients with chronic hepatitis B virus infection and naturally immunized individuals. Internal Medicine Inside. 2013; 1:2.

16. Uçar F, Taşlıpınar MY, Soydaş AÖ, Özcan N. Ankara Etlik Ihtisas Eğitim Araştırma Hastanesi'ne Başvuran Hastalarda 25-OH Vitamin D Düzeyleri. Eur J Basic Med Sci. 2012; 2: 12-15.

17. Farnik $H$, Bojunga $J$, Berger $A$, Allwinn $R$, Waidmann $O$, Kronenberger B, Keppler OT, Zeuzem S, Sarrazin C, Lange CM. Low vitamin $D$ serum concentration is associated with high levels of hepatitis B virus replication in chronically infected patients. Hepatology. 2013; 58: 1270-1276. 